\title{
RENOVAR E INDEXAR A REVISTA DA SPDV
}

\section{INDEXING AT MEDLINE OF THE JOURNAL OF THE PORTUGUESE SOCIETY OF DERMATOLOGY AND VENEREOLOGY}

\section{Caros colegas}

Desde a sua fundação, há mais de meio século, e até ao presente a Dermatologia Nacional tem mantido atividade científica regular e de elevada qualidade, traduzida nas participadas reuniões científicas e congressos organizados pela Sociedade Portuguesa de Dermatologia e Venereologia (SPDV) ou pelos seus grupos de trabalho, além da crescente participação de Dermatologistas Portugueses em grupos de trabalho, reuniões e publicações internacionais.

A Revista da Sociedade Portuguesa de Dermatologia e Venereologia, em continuação dos Trabalhos da SPDV, tem-se esforçado para espelhar esta atividade mas a sua não indexação na Medline tem sido um forte entrave à escolha da nossa revista para publicitação do trabalho nacional. Estamos já indexados no IRMP - Index das Revistas Médicas Portuguesas, no ICMJE - International Committee of Medical Journal Editors - e só por um erro técnico perdemos transitoriamente a indexação na Scielo - Scientific Electronic Library online. Estivemos muito perto de conseguir a indexação na Medline e em breve vamos fazer nova tentativa. Para atingirmos este objetivo necessitamos da colaboração de todos os Dermatologistas Nacionais.

Vamos publicar os nossos trabalhos de investigação, os nossos estudos clínicos, os nossos casos clínicos na Nossa revista. Vamos elaborar mais artigos de revisão com referências atualizadas e, eventualmente, em colaboração com colegas estrangeiros reconhecidos na matéria. A escrita em inglês, cada vez acessível a maior número de colegas, pode e deve progressivamente substituir a nossa língua para aumentar a visibilidade da revista fora de portas, sem prejuízo de mantermos a nossa identidade. A Língua Portuguesa continuará a figurar em muitas partes da revista em paralelo com a língua inglesa.

A renovação do Corpo Editorial com a inclusão de colegas dos principais centros do país, colegas experientes mais jovens mas com ideias refrescadas e de grande dinamismo, vai permitir a apreciação imparcial e criteriosa de todos os trabalhos submetidos com o intuito de os valorizar. Só com o contributo de todos e a discussão aberta das questões científicas resulta uma Revista melhor com consequente benefício para a Dermatologia Nacional e, em último caso, para os nossos pacientes.

Aproveitamos para agradecer a todos os colegas que têm contribuído para a Revista e, em particular, àqueles que pertenceram ao seu Corpo Editorial nos últimos anos. Gostaríamos de ter todos os Dermatologistas no Conselho Editorial mas, apenas por limitação de número sugerido pelos avaliadores da Medline, tal não é possível. Esperamos, contudo, que todos participem da mesma forma.

Vamos todos publicar ou promover a publicação na Revista da SPDV. É a Revista de todos os Dermatologistas Portugueses e representa a nossa imagem que queremos melhorar.

A Editora chefe

Gabriela M Pinto
A Editora adjunta

Margarida Gonçalo
O Presidente da SPDV

António Massa 